\title{
Studi Pemisahan Thorium dari Besi dan Logam Tanah Jarang dalam Larutan Asam Nitrat dengan Ekstraksi Pelarut Menggunakan Ekstraktan Trioctylphosphine Oxide
}

\section{Study of Thorium Seperation from Iron and Rare Earth Metals in Nitric Acid Solution by Solvent Extraction Using Trioctylphosphine Oxide}

\author{
Briliant $^{1 *}$, Mohammad Zaki Mubarok ${ }^{1}$, Kurnia Trinopiawan ${ }^{2}$, Riesna Prassanti $^{2}$ \\ ${ }^{1}$ Program Studi Teknik Metalurgi, ITB, Jl. Ganesha No.10, Bandung, Indonesia, 40132 \\ ${ }^{2}$ Pusat Teknologi Bahan Galian Nuklir-BATAN, Jl. Lebak Bulus Raya No.9, Ps. Jumat, Jakarta, Indonesia, 12440 \\ *E-mail: briliantlie@gmail.com
}

Naskah diterima: 25 November 2017, direvisi: 28 November 2017, disetujui: 30 November 2017

DOI: https://doi/org/10.17146/eksplorium.2017.38.2.3924

\begin{abstract}
ABSTRAK
Serangkaian percobaan ekstraksi pelarut untuk memisahkan thorium dari besi (Fe) dan logam tanah jarang (LTJ) menggunakan trioctylphosphine oxide (TOPO) dilakukan dengan variasi konsentrasi asam nitrat, waktu ekstraksi, nisbah ekstraktan terhadap diluen $(\mathrm{g} / \mathrm{mL})$, dan variasi nisbah volume larutan organik terhadap volume larutan aqueous (O/A) serta variasi konsentrasi asam pada proses stripping. Konsentrasi awal thorium, besi, dan LTJ dalam larutan umpan diukur masing-masing dengan Inductively Coupling Plasma (ICP), Atomic Absorption Spectroscopy (AAS), dan Ultraviolet Visible Spectroscopy (Spektro UV-VIS). Konsentrasi asam nitrat divariasikan pada 1M, 2M, 3M, 4M, dan 5M. Waktu ekstraksi divariasikan pada 2, 5, 10, 15, dan 20 menit, sementara nisbah ekstraktan terhadap diluen $(\mathrm{g} / \mathrm{mL})$ divariasikan pada 2:100, 3:100, 4:100, 5:100, dan 6:100 dengan variasi nisbah O/A yaitu 1:3, 1:2, 1:1, 2:1, dan 3:1. Pada tahap stripping dilakukan variasi konsentrasi asam nitrat pada $0,1 \mathrm{M} ; 0,2 \mathrm{M} ; 0,3 \mathrm{M} ; 0,4 \mathrm{M}$; dan 0,5 M. Hasil percobaan menunjukkan kondisi terbaik dicapai pada konsentrasi asam nitrat 3M, waktu ekstraksi 10 menit, nisbah ekstraktan terhadap diluen sebesar 5:100 (g/mL), dan nisbah O/A sebesar 1:1 sehingga didapatkan persen ekstraksi Th sebesar 97,26\%, Fe sebesar 7,97\%, dan LTJ sebesar $62,15 \%$ dengan nilai $\beta_{\text {Th-Fe }}$ dan $\beta_{\text {Th-LTJ }}$ masing-masing sebesar 273,62 dan 14,43. Pada percobaan stripping didapatkan persen stripping Th tertinggi sebesar $51,37 \%$ pada konsentrasi asam nitrat $0,3 \mathrm{M}$ dengan persen stripping Fe dan LTJ masing-masing sebesar 2,72\% dan 2,55\%.
\end{abstract}

Kata kunci: ekstraksi pelarut, thorium, besi, logam tanah jarang, trioctylphospine oxide

\section{ABSTRACT}

A series of solvent extraction experiment to separate thorium(Th) from iron (Fe) and rare earth metals (REE) using trioctylphosphine oxide (TOPO) conducted with variations of nitric acid concentration, extraction time, ratio between exctractan and diluent $(\mathrm{g} / \mathrm{mL})$, and ratio between organic solution and aqueous solution volumes (O/A), and variation of nictric acid concentration in stripping process. Thorium, iron and rare earth metals early concentration in solution feed were measured by using Inductively Coupling Plasma (ICP), Atomic Absorption Spectroscopy (AAS), dan Ultraviolet Visible Spectroscopy (UV-VIS Spectro) respectively. The nitric acid concentration was varied at $1 \mathrm{M}, 2 \mathrm{M}, 3 \mathrm{M}, 4 \mathrm{M}$, and $5 \mathrm{M}$. The extraction time was varied at 2, 5, 10, 15, and 20 minutes, meanwhile the ratio between extractan and diluent $(\mathrm{g} / \mathrm{mL})$ was varied at 2:100, 3:100, 4:100, 5:100, and $6: 100$ with $0 / A$ ratio at 1:3, 1:2, 1:1, 2:1, and 3:1. At stripping stage, the nitric acid concentration was varied at $0.1 \mathrm{M} ; 0.2 \mathrm{M} ; 0.3 \mathrm{M} ; 0.4 \mathrm{M}$; and $0.5 \mathrm{M}$. The result of the experiments show that the best condition was obtained on 
3M nitric acid concentration, 10 minutes extraction time, 5:100 $(\mathrm{g} / \mathrm{mL})$ extractan and diluent ratio, and 1:1 O/A ratio, that resulted in $97.26 \%$ Th extraction, $7.97 \%$ Fe extraction, and $62.15 \%$ rare earth metals extraction with $\beta_{T h-F e}$ and $\beta_{T h-R E E}$ value 273.62 and 14.43 respectively. On the stripping experiment, the highest Th stripping percentage obtained as much as $51.37 \%$ at $0.3 \mathrm{M}$ nitric acid concentration with Fe and REE stripping percentage up to $2.72 \%$ and $2.55 \%$ respectively.

Keywords: solvent extraction, thorium, iron, rare earth metals, trioctylphosphine oxide

\section{PENDAHULUAN}

Thorium merupakan logam yang bersifat radioaktif dan memiliki waktu paruh sangat panjang, yaitu sekitar 14,05 juta tahun [1]. Saat ini, thorium banyak digunakan sebagai campuran dengan gas tungsten untuk pengelasan, paduan pada pembuatan keramik, dan alat-alat optik dimana penggunaan thorium pada aplikasi tersebut dalam bentuk oksidanya. Salah satu keunggulan penggunaan thorium dioksida, yaitu titik lelehnya yang sangat tinggi hingga mencapai $3.300^{\circ} \mathrm{C}$ [1]. Selain itu, thorium juga dapat digunakan sebagai bahan bakar nuklir alternatif pengganti uranium.

Penggunaan bahan bakar nuklir yang paling umum adalah sebagai pembangkit tenaga listrik. Pada pembangkit listrik tenaga nuklir (PLTN) bahan bakar nuklir yang bersifat fisil (dapat membelah) akan direaksikan dengan neutron sehingga terjadi reaksi fisi yang akan menghasilkan energi panas dalam jumlah yang besar. Panas yang dihasilkan dari reaksi fisi ini dimanfaatkan untuk memutar turbin dan menghasilkan energi listrik.Pembangkit listrik tenaga nuklir ini dapat menghasilkan energi listrik yang cukup besar persatuan berat bahan bakar nuklir yang digunakan dibandingkan bahan bakar lainnya, misalnya batubara dan minyak.

Pengembangan pembangkit listrik tenaga nuklir ini menjadi sangat penting khususnya untuk Indonesia karena kebutuhan listrik di Indonesia terus meningkat seiring dengan meningkatnya jumlah industri dan penduduk di Indonesia. Berdasarkan data dari Kementerian ESDM, pada tahun 2012 total kebutuhan listrik di Indonesia mencapai 174 TWh, meningkat $10,1 \%$ dibandingkan dengan kebutuhan listrik periode sebelumnya. Berdasarkan data tersebut, dapat diprediksi bahwa kebutuhan tenaga listrik pada tahun 2025 akan mencapai 520 TWh dan akan terus meningkat hingga 2.200 TWh pada tahun 2050 [2].

Thorium menjadi alternatif untuk bahan bakar nuklir karena keberadaannya di alam lebih melimpah dibandingkan dengan uranium, yaitu sekitar $6,6-7,4$ juta ton yang ada di seluruh dunia [3]. Indonesia diperkirakan memiliki cadangan thorium sebesar 130.974 ton yang tersebar di beberapa wilayah seperti Pulau Singkep, Bangka Belitung, Kalimantan Barat, dan Mamuju [4]. Selain itu, jumlah thorium yang dapat bereaksi sebagai bahan bakar tenaga nuklir mencapai $90 \%$ dari total beratnya dan lebih efektif dibandingkan dengan uranium yang hanya sebesar 3-5\% sehingga dapat mengurangi limbah radioaktif yang dihasilkan setelah proses berlangsung. Oleh karena itu, thorium sangat berpotensi untuk menjadi alternatif bahan bakar nuklir untuk PLTN.

Sebelum dapat digunakan sebagai bahan bakar untuk PLTN, thorium yang berada dialam harus diolah terlebih dahulu menjadi thorium oksida dengan kadar tertentu. Karena keberadaannya di alam seringkali berikatan 
dengan logam tanah jarang, metode pengolahan thorium hampir sama dan seiring dengan pengolahan logam tanah jarang. Proses yang sering digunakan yaitu melalui jalur hidrometalurgi. Proses hidrometalurgi telah terbukti efektif untuk mengolah logam tanah jarang dan thorium. Hal ini disebabkan karena sifat kimia dari logam-logam ini mudah untuk dilarutkan dan dipresipitasi secara selektif [5].

Salah satu daerah yang cukup berpotensi memiliki cadangan thorium adalah Kabupaten Mamuju, Provinsi Sulawesi Barat. Hasil analisis Pusat Teknologi Bahan Galian Nuklir, Badan Tenaga Nuklir Nasional (PTBGN-BATAN) kadar Th dalam bijih thorit dari Mamuju sebesar 71.726 ppm dengan kandungan silika yang cukup tinggi, yaitu sebesar $32,46 \%$. Selain itu, kandungan besinya juga tinggi hingga mencapai $24,67 \%$ sehingga menimbulkan permasalahan dalam proses pengolahan dan pemurnian thorium. Hal ini karena besi ikut terpresipitasi dengan thorium pada tahap presipitasi setelah proses pelindian. Salah satu metode yang efektif untuk digunakan dalam proses pemurnian thorium adalah ekstraksi pelarut. Beberapa jenis ekstraktan yang telah diteliti ataupun digunakan secara komersial diantaranya tributylphosphate (TBP), Cyanex302 [bis(2,4,4-trimethylpentyl) thiophosphinic acid], Cyanex272 [bis (2,4,4-trimethylpentyl) phosphinic acid], Adogen-383 (secondary amine), Prime JM-T (primary amine) [6].

Penelitian pemurnian thorium menggunakan ekstraktan Trioctylphosphine Oxide (TOPO) juga telah dilakukan pada larutan hasil pelindian mineral monasit. Hasil penelitian menunjukkan bahwa persentase ekstraksi thorium yang dihasilkan lebih tinggi bila dibandingkan dengan ekstraktan lain [7]. TOPO merupakan senyawa organophosporus dengan rumus molekul $\left(\mathrm{C}_{8} \mathrm{H}_{17}\right)_{3} \mathrm{PO}$. Adapun struktur molekulnya dapat dilihat pada gambar 1.

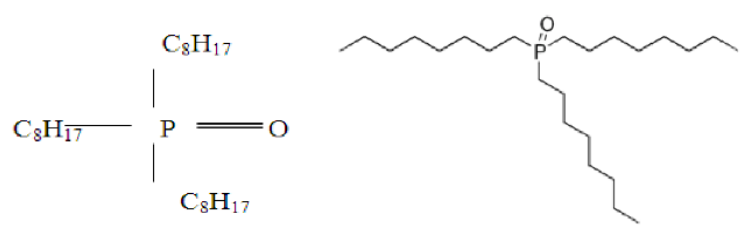

Gambar 1. Struktur molekul TOPO

Dalam penelitian ini, dipelajari metode pemisahan thorium dari besi dan logam tanah jarang (LTJ) dengan ekstraksi pelarut menggunakan TOPO. Larutan umpan ekstraksi pelarut yang digunakan diperoleh dari hasil pelarutan kembali presipitat Th, Fe, dan LTJ-hidroksida dalam larutan asam nitrat. Presipitat hidroksida tersebut diperoleh dari proses digesti asam bijih thorit dari Mamuju yang diikuti pelindian dalam air dan netralisasi menggunakan larutan amonium hidroksida.

\section{TEORI}

Bijih thorium keberadaannya di alam biasanya berikatan dengan logam tanah jarang sehingga metode pengolahan thorium hampir sama dan beriringan dengan pengolahan logam tanah jarang. Proses pengolahannya meliputi proses fisik dan proses kimia yang dilakukan untuk mendapatkan logam yang diinginkan dari bijih. Proses pengolahan secara fisik biasanya dilakukan dengan gravity separation, magnetic separation, electrostatic separation, dan flotasi. Setelah melalui proses fisik, konsentrat diproses lebih lanjut untuk mengekstraksi thorium dan LTJ di dalamnya, baik dengan jalur pirometalurgi maupun hidrometalurgi. Jalur hidrometalurgi lebih banyak digunakan karena thorium dan LTJ relatif mudah dilarutkan dalam asam dan basa dan selanjutnya dapat dipisahkan dengan metode-metode seperti proses presipitasi 
kimia, ekstraksi pelarut, adsorpsi selektif dengan resin, dan metode lainnya [9].

Ekstraksi pelarut merupakan suatu metode untuk memurnikan larutan kaya hasil dari pelindian dengan menggunakan larutan organik. Selama proses berlangsung, larutan kaya akan dikontakkan dengan larutan organik, kemudian logam tertentu akan bereaksi dengan larutan organik dan membentuk senyawa komplek organometallic. Proses ekstraksi pelarut umumnya terdiri dari tiga tahap, yaitu tahap ekstraksi, scrubbing, dan stripping. Pada tahap ekstraksi, logam tertentu dalam larutan kaya yang dikontakkan dengan larutan organik akan bereaksi dan berpindah ke fase organik. Reaksi sederhana yang terjadi dalam proses ini dapat dinyatakan dengan persamaan berikut:

$$
\mathrm{M}+\bar{E} \leftrightarrow \overline{M E}
$$

Nilai $\mathrm{M}$ adalah logam yang berada pada fase aqueous, E adalah ekstraktan organik yang digunakan, dan ME adalah komplek organometallic yang terbentuk.

Selama proses ekstraksi, logam yang tidak diinginkan dapat terbawa ke larutan organik atau terko-ekstraksi. Hal ini berhubungan dengan selektivitas dari larutan organik itu sendiri. Keberhasilan dari proses ekstraksi logam dapat dilihat dari beberapa hal, antara lain persentase ekstraksi (\%E) dan koefisien distribusi (D). Persentase ekstraksi logam dapat didefinisikan sebagai banyaknya logam yang berpindah dari larutan kaya (aqueous) ke larutan organik. Persamaannya dapat dituliskan sebagai berikut:

$$
\begin{aligned}
& \% E_{M}=\frac{w_{o}}{w_{a}} \times 100 \%=\frac{w_{a}-w_{r}}{w_{a}} \times 100 \% \\
& D_{M}=\frac{W_{o} / O}{w_{r} / A}=\frac{w_{a}-w_{r} / O}{W_{r} / A}
\end{aligned}
$$

Nilai $\mathrm{W}_{\mathrm{o}}$ adalah berat logam pada fase organik, $\mathrm{O}$ adalah volume larutan organik, $\mathrm{W}_{\mathrm{r}}$ adalah berat logam mula-mula dalam larutan aqueous, dan A adalah volume larutan aqueouos.

Parameter lain yang dapat menunjukkan keberhasilan proses ekstraksi adalah faktor pemisahan $(\beta)$. Faktor pemisahan menunjukkan seberapa banyak logam $\mathrm{N}$ yang ikut terbawa oleh larutan organik atau terekstraksi bersama dengan logam $\mathrm{M}$ sehingga dapat mengindikasikan keterpisahan dari dua logam tersebut. Persamaan dari faktor pemisahan logam $M$ dan $N\left(\beta_{M-N}\right)$ adalah sebagai berikut [9]:

$\beta_{M-N}=\frac{D_{M}}{D_{N}}$

\section{METODOLOGI}

Percobaan yang dilakukan pada penelitian ini terdiri dari beberapa tahap, yaitu dimulai dengan proses preparasi bijih yang dilanjutkan dengan proses digesti asam menggunakan asam sulfat dengan konsentrasi 98\%. Proses digesti asam menghasilkan gray mud yang terdiri dari Th, Fe, dan LTJ-sulfat yang masih bercampur dengan silika dan pengotor lainnya. Gray mud tersebut kemudian dilarutkan dalam air untuk memisahkan silika dan pengotor lainnya yang tidak larut dalam air dengan Th, Fe, dan LTJsulfat yang larut dengan cara filtrasi. Larutan yang mengandung Th, Fe, dan LTJ-sulfat kemudian dilakukan netralisasi dengan menambahkan larutan amonium hidroksida untuk mempresipitasi Th. Oleh karena Fe dan LTJ juga ikut terpresipitasi, selanjutnya dilakukan serangkaian percobaan pemisahan ketiga logam ini dengan ekstraksi pelarut. Dalam proses ekstraksi pelarut ini, 
diharapkan thorium dapat berpindah ke fase organik sementara Fe dan LTJ tetap berada pada fase aqueous. Pelepasan kembali thorium dari fase organik dilakukan dengan proses stripping menggunakan larutan asam nitrat. Untuk mengetahui kandungan logam thorium, besi, dan LTJ pada setiap larutan aqueous yang dihasilkan dilakukan analisis masing-masing dengan Inductively Coupling Plasma (ICP), Atomic Absorption Spectroscopy (AAS), dan Ultraviolet Visible Spectroscopy (Spektro UV-VIS). Prosedur percobaan yang dilakukan ditunjukkan secara skematik pada Gambar 2.

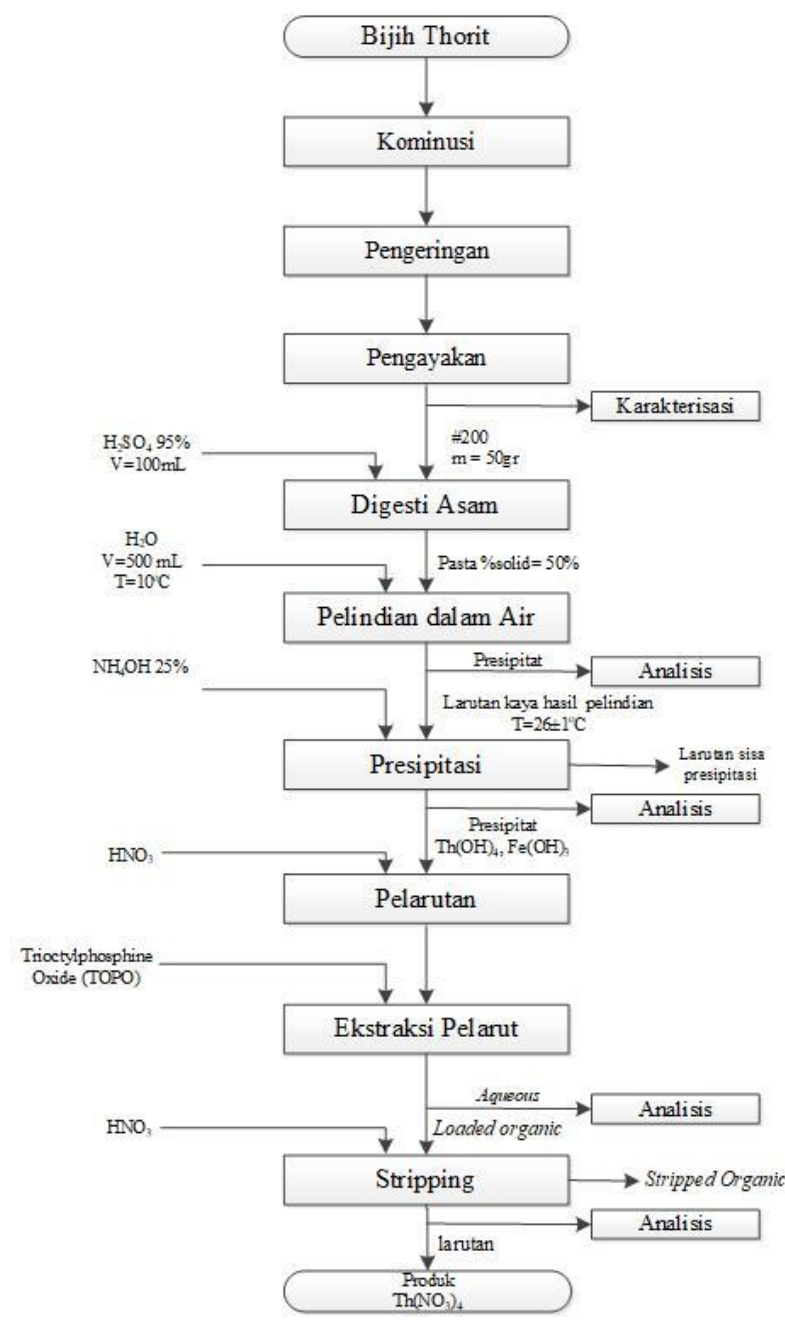

Gambar 2. Diagram alir prosedur percobaan.

\section{Preparasi Bijih}

Bijih yang berasal dari daerah Mamuju, Sulawesi Barat dipreparasi di laboratorium Pusat Teknologi Bahan Galian Nuklir (PTBGN). Pertama, bijih dihomogenisasi terlebih dahulu kemudian dilakukan proses peremukan dengan menggunakan jaw crusher. Selanjutnya, dilakukan penggerusan dengan rod mill dengan perbandingan berat antara bijih dengan batang penggerus adalah 1:4 selama 1 jam. Setelah proses penggerusan, dilakukan proses pengayakan untuk mendapatkan bijih yang lolos ayakan berukuran 200 mesh yang akan digunakan sebagai umpan proses digesti asam dan sebagian untuk karakterisasi dengan $X$-Ray Diffraction (XRD) dan X-Ray Fluoresence (XRF).

\section{Percobaan Digesti Asam}

Digesti asam dilakukan di dalam gelas beaker berukuran $300 \mathrm{~mL}$ dengan penutup polimer. Alat yang digunakan pada proses digesti asam adalah mechanical stirrer sebagai pengaduk dan hotplate sebagai pemanas seperti yang ditunjukkan pada gambar 3. Proses digesti asam dilakukan secara batch dimana 50 gram bijih dilarutkan di dalam $100 \mathrm{~mL} \mathrm{H}_{2} \mathrm{SO}_{4} 95 \%$. Proses digesti asam diawali dengan memanaskan $\mathrm{H}_{2} \mathrm{SO}_{4}$ hingga suhunya mencapai $160^{\circ} \mathrm{C}$, kemudian bijih dimasukkan dan diaduk selama satu jam. Selanjutnya, gray mud yang terbentuk dari proses digesti asam dilarutkan di dalam air untuk memisahkan silika dan pengotor lainnya dengan Th, Fe, dan LTJ-sulfat dengan metode filtrasi menggunakan vacuum filter. 


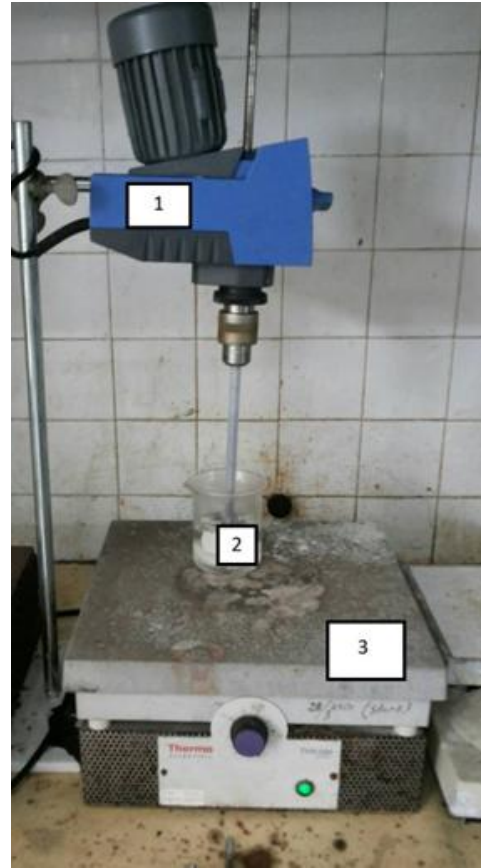

Gambar 3. Rangkaian alat proses digesti asam: (1) Mechanic stirrer; (2) Gelas kimia; dan (3) Hot plate.

\section{Percobaan Presipitasi}

Proses presipitasi dilakukan dengan menambahkan larutan ammonium hidroksida $25 \%$ tetes demi tetes ke dalam larutan filtrat digesti asam hingga pHnya mencapai 4,5. Setelah $\mathrm{pH}$ larutan mencapai 4,5, larutan didiamkan sebentar lalu difiltrasi dengan vacuum filter untuk diambil padatannya lalu dikeringkan dengan menggunakan oven selama 8 jam pada suhu $105^{\circ} \mathrm{C}$. Kemudian, presipitat hasil proses presipitasi dilarutkan kembali dalam asam nitrat dan digunakan sebagai umpan percobaan ekstraksi pelarut. Rangkaian alat untuk percobaan presipitasi dan contoh foto presipitat yang diperoleh masing masing ditunjukkan pada Gambar 4 dan Gambar 5.

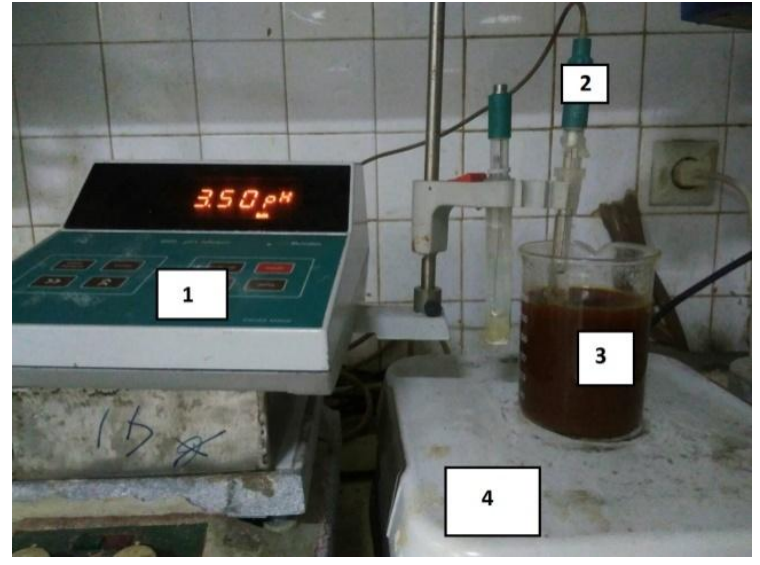

Gambar 4. Rangkaian alat pada percobaan presipitasi filtrat hasil digesti asam (1) $\mathrm{pH}$ meter; (2) Probe $\mathrm{pH}$ meter; (3) Gelas kimia; dan (4) magnetic stirrer.

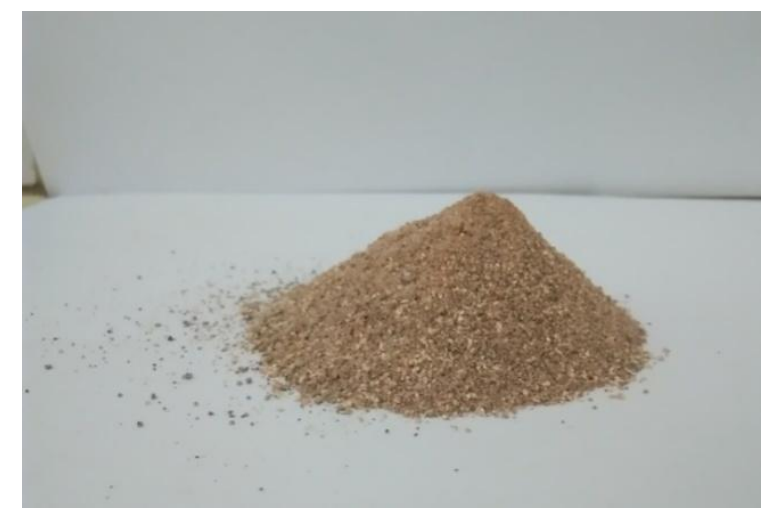

Gambar 5. Prespitat hasil presipitasi larutan hasil digesti asam pada $\mathrm{pH} 4,5$.

\section{Percobaan Ekstraksi Pelarut}

Sebelum digunakan dalam percobaan ekstraksi pelarut, presipitat dilarutkan dalam asam nitrat yang konsentrasinya divariasikan pada 1M, 2M, 3M, 4M, dan 5M. Ekstraktan yang digunakan adalah Trioctylphosphine Oxide (TOPO) yang diencerkan dalam kerosen. Nisbah ekstraktan terhadap diluen divariasikan pada 2:100, 3:100, 4:100, 5:100, dan 6:100 $(\mathrm{g} / \mathrm{mL})$. Proses ekstraksi dilakukan pada suhu $80^{\circ} \mathrm{C}$ dengan cara memanaskan ekstraktan dan larutan umpan terlebih dahulu hingga mencapai temperatur tersebut secara terpisah. Kemudian, ekstraktan dan larutan umpan dicampurkan lalu diaduk selama 2, 5, 10, 15, dan 20 menit. Dalam proses ekstraksi 
diharapkan pemakaian larutan organik sekecil mungkin namun tetap mendapatkan persentase ekstraksi Th yang maksimal. Dalam percobaan yang dilakukan, dipelajari pengaruh dari variasi nisbah $\mathrm{O} / \mathrm{A}$ terhadap persentase ekstraksi Th, dimana variasi nisbah O/A dilakukan pada $1: 3 ; 1: 2 ; 1: 1 ; 2: 1$; dan 3:1. Selama proses ekstraksi berlangsung, temperatur larutan dijaga tetap dengan mengatur temperatur pemanasan dari hot plate.

\section{Percobaan Stripping}

Percobaan dilakukan untuk mengevaluasi pengaruh konsentrasi asam nitrat terhadap persentase stripping $\mathrm{Th}, \mathrm{Fe}$, dan LTJ. Percobaan stripping dilakukan di dalam gelas kimia dengan volume $150 \mathrm{~mL}$. Larutan organik yang digunakan adalah larutan organik yang dihasilkan dari kondisi terbaik pada percobaan ekstraksi pelarut sebelumnya, yaitu pada konsentrasi asam nitrat $3 \mathrm{M}$, waktu ekstraksi 10 menit, nisbah ekstraktan terhadap diluen 5:100, dan nisbah O/A 1:1. Larutan aqueous yang digunakan sebagai stripping agent adalah larutan asam nitrat dengan konsentrasi yang divariasikan pada $0,1 \mathrm{M}, 0,2$ M, 0,3 M, 0,4 M, dan 0,5 M.

Setiap percobaan dilakukan dengan menggunakan $20 \mathrm{ml}$ larutan organik hasil ekstraksi dan $80 \mathrm{ml}$ larutan aqueous. Larutan diaduk selama 10 menit menggunakan magnetic stirrer pada temperatur ruangan. Setelah proses stripping selesai, larutan aqueous dipisahkan dari larutan organik dengan menggunakan separatory funnel seperti ditunjukkan pada Gambar 6.

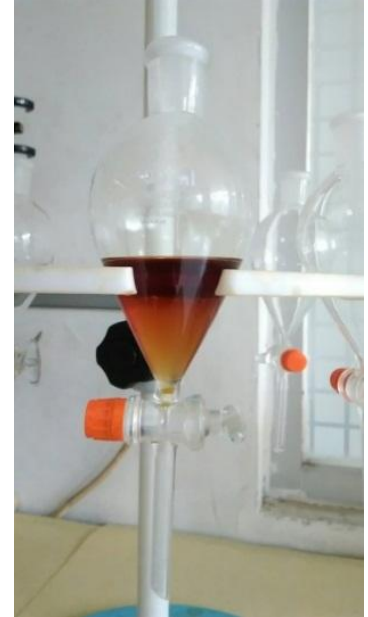

Gambar 6. Pemisahan fase organik dengan fase aqueous.

\section{HASIL DAN PEMBAHASAN}

Analisis dengan menggunakan XRF dilakukan untuk mengetahui komposisi unsur dominan yang terkandung di dalam presipitat sebelum dilarutkan dalam asam nitrat. Hasil analisis konsentrasi unsur-unsur dominan dalam presipitat dengan XRF tesebut ditunjukkan pada tabel 1 .

Tabel 1. Hasil analisis konsentrasi unsur-unsur dominan dalam presipitat menggunakan XRF.

\begin{tabular}{cr} 
Unsur & Konsentrasi \\
\hline $\mathrm{Si}$ & $1,087 \mathrm{ppm}$ \\
$\mathrm{Mg}$ & $53,8 \mathrm{ppm}$ \\
$\mathrm{Fe}$ & $108,300 \mathrm{ppm}$ \\
$\mathrm{Cu}$ & $45,6 \mathrm{ppm}$ \\
$\mathrm{Zn}$ & $13,3 \mathrm{ppm}$ \\
$\mathrm{Pb}$ & $111,4 \mathrm{ppm}$ \\
$\mathrm{Th}$ & $50,040 \mathrm{ppm}$ \\
$\mathrm{U}$ & $730,7 \mathrm{ppm}$ \\
$\mathrm{LTJ}$ & $6807,84 \mathrm{ppm}$ \\
\hline
\end{tabular}

\section{Pengaruh Konsentrasi Asam Nitrat terhadap Ekstraksi Logam}

Grafik persentase ekstraksi logam Th, Fe, dan LTJ sebagai fungsi konsentrasi asam ditunjukkan pada gambar 7. Persentase ekstraksi thorium meningkat seiring dengan meningkatnya keasaman larutan. Namun, saat konsentrasi asam nitrat melebihi $3 \mathrm{M}$, 
persentase ekstraksi thorium menurun. Hasil percobaan ini mirip dengan hasil percobaan ekstraksi thorium dengan TOPO yang dilarutkan dengan toluene [9]. Penurunan persentase ekstraksi thorium dapat terjadi karena asam ikut terekstraksi oleh TOPO pada konsentrasi asam yang melebihi level tertentu. Ekstraksi asam oleh TOPO ditunjukkan pada persamaan berikut [10]:

$$
\mathrm{H}^{+}+\mathrm{NO}_{3}^{-}+\overline{T O P O} \leftrightarrow \overline{\mathrm{HNO}_{3 .} \mathrm{TOPO}}
$$

Berdasarkan hasil percobaan tersebut maka konsentrasi asam nitrat $3 \mathrm{M}$ merupakan konsentrasi terbaik untuk melakukan proses ekstraksi thorium dengan TOPO dengan perolehan persentase ekstraksi thorium sebesar 97,26\%. Selektivitas ekstraksi terhadap besi cukup baik dimana pada kondisi terbaik tersebut diperoleh persentase ekstraksi besi sebesar 7,97\%. Sementara selektivitas ekstraksi terhadap LTJ kurang baik dimana pada kondisi tersebut didapatkan persentase ekstraksi LTJ sebesar 62,15\%.

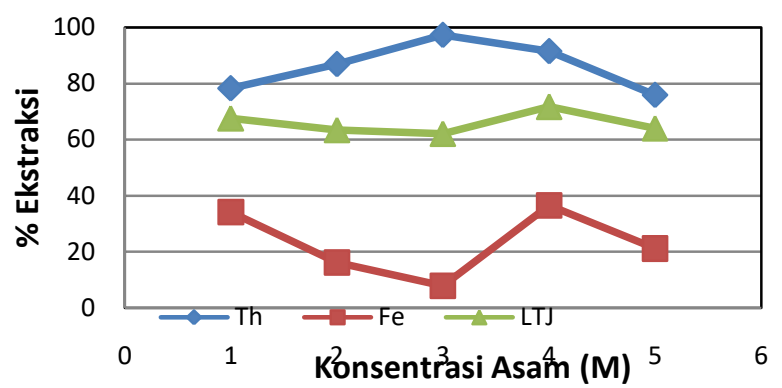

Gambar 7. Persentase ekstraksi Fe, Th, dan LTJ pada suhu $80^{\circ} \mathrm{C}$, waktu ekstraksi 10 menit, nisbah ekstraktan dengan diluen 5:100 $(\mathrm{g} / \mathrm{mL})$, dan nisbah O/A sebesar $1: 1$.

Berdasarkan data-data persentase esktraksi Th, Fe, dan LTJ pada kondisi terbaik diperoleh nilai $\beta_{\text {Th-Fe }}$ dan $\beta_{\text {Th-LTJ }}$ masing-masing sebesar 273,62 dan 14,43. Sementara itu, nilai koefisien distribusi thorium $\left(\mathrm{D}_{\mathrm{Th}}\right)$ pada kondisi tersebut sebesar
31,39 dan $\mathrm{D}_{\mathrm{Fe}}$ sebesar 0,11 . Nilai $\mathrm{D}_{\text {Th }}$ yang besar menunjukkan jumlah Th yang berada dalam fase organik jauh lebih banyak dibandingkan dengan yang ada di fase aqueous pada keadaan kesetimbangan. Sebaliknya, nilai dari nilai $\mathrm{D}_{\mathrm{Fe}}$ yang kecil menunjukkan jumlah $\mathrm{Fe}$ yang berada pada fase aqueous lebih banyak dibandingkan dengan yang ada di fase organik pada keadaan kesetimbangan. Profil dari D untuk Th, Fe dan LTJ sebagai fungsi konsentrasi asam (pada suhu $80^{\circ} \mathrm{C}$, waktu ekstraksi 10 menit, nisbah ekstraktan terhadap diluen sebesar 5:100, dan nisbah O/A sebesar 1:1) dapat dilihat pada gambar 8 .

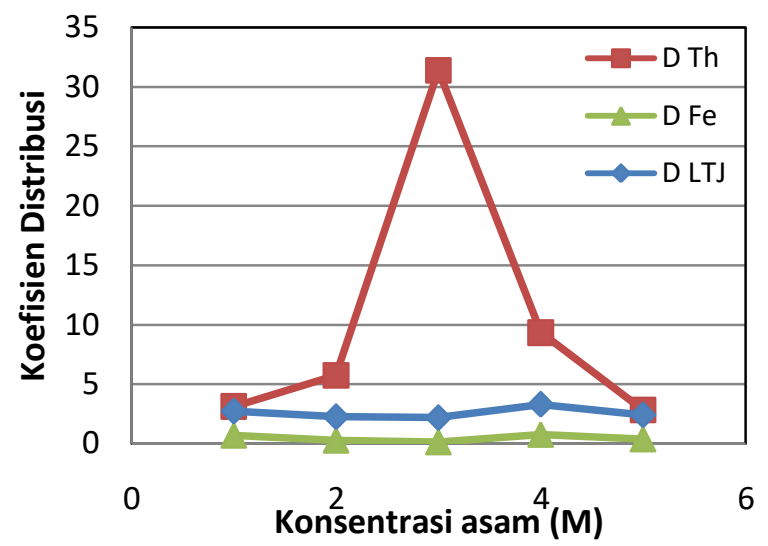

Gambar 8. Profil $\mathrm{D}_{\mathrm{Th}}, \mathrm{D}_{\mathrm{Fe}}$, dan $\mathrm{D}_{\mathrm{LTJ}}$ pada suhu $80^{\circ} \mathrm{C}$, waktu ekstraksi 10 menit, nisbah ekstraktan terhadap diluen sebesar 5:100, dan nisbah O/A sebesar 1:1.

\section{Pengaruh Waktu Ekstraksi terhadap Ekstraksi Logam}

Profil persentase ekstraksi $\mathrm{Th}, \mathrm{Fe}$, dan LTJ sebagai fungsi waktu pada suhu $80^{\circ} \mathrm{C}$, konsentrasi asam nitrat $3 \mathrm{M}$, nisbah ekstraktan terhadap diluen 5:100 ( $\mathrm{g} / \mathrm{mL})$, dan nisbah O/A 1:1 ditunjukkan pada gambar 9. Dapat dilihat bahwa persentase ekstraksi thorium meningkat dari menit ke-2 sampai ke-10 dan mulai menurun pada saat menit ke-15. Kecenderungan persentase ekstraksi seperti ini mirip dengan hasil ekstraksi pelarut thorium menggunakan TOPO dengan larutan thorium artifisial berbasis nitrat [7]. 


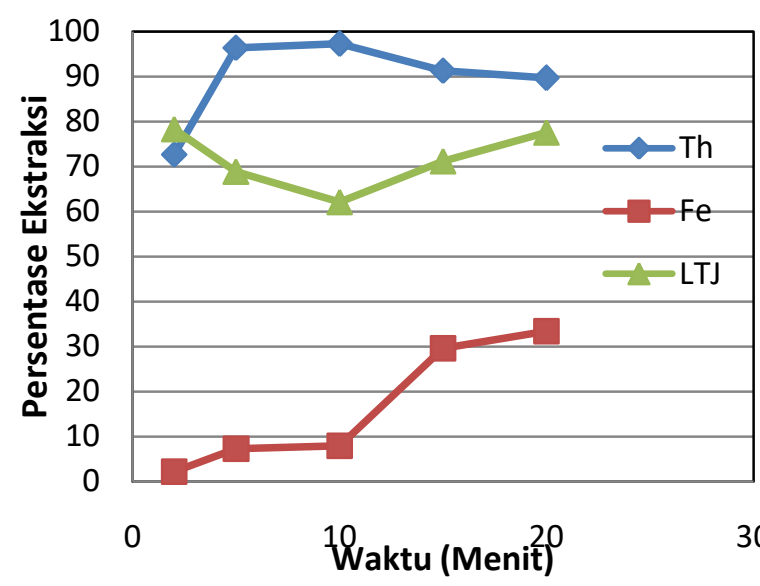

Gambar 9. Persentase ekstraksi Fe, Th, dan LTJ pada suhu $80^{\circ} \mathrm{C}$, konsentrasi asam nitrat $3 \mathrm{M}$, nisbah ekstraktan terhadap diluen 5:100, dan nisbah O/A sebesar 1:1.

Hasil percobaan ini mengindikasikan bahwa reaksi ekstraksi Th oleh TOPO bersifat reversible dimana setelah kesetimbangan tercapai dan proses pengadukan dilakukan dalam waktu yang lebih lama maka kompleks $\mathrm{Th}\left(\mathrm{NO}_{3}\right)_{4}$.nTOPO kembali terurai menjadi $\mathrm{Th}^{4+}$ dan $\mathrm{NO}_{3}{ }^{-}$yang kembali ke fase aqueous, seperti yang ditunjukkan pada persamaan berikut:

$\mathrm{Th}^{4+}+4 \mathrm{NO}_{3}^{-}+n \mathrm{TOPO}$

$\stackrel{K_{T h}}{\longleftrightarrow} \mathrm{Th}\left(\mathrm{NO}_{3}\right)_{4} \cdot n \mathrm{TOPO}$

Berdasarkan hasil percobaan yang diperoleh waktu 10 menit adalah waktu terbaik yang digunakan untuk percobaan selanjutnya dengan variasi nisbah ekstraktan terhadap diluen $(\mathrm{g} / \mathrm{mL})$. Pada kondisi terbaik ini diperoleh persentase ekstraksi thorium sebesar 97,26\% dengan besi dan LTJ yang ikut terekstraksi masing masing sebesar 7,97\% dan 62,15\%. Profil $\mathrm{D}_{\mathrm{Th}}, \mathrm{D}_{\mathrm{Fe}}$, dan $\mathrm{D}_{\mathrm{LTJ}}$ pada kondisi terbaik ini ditunjukkan pada gambar 10 .

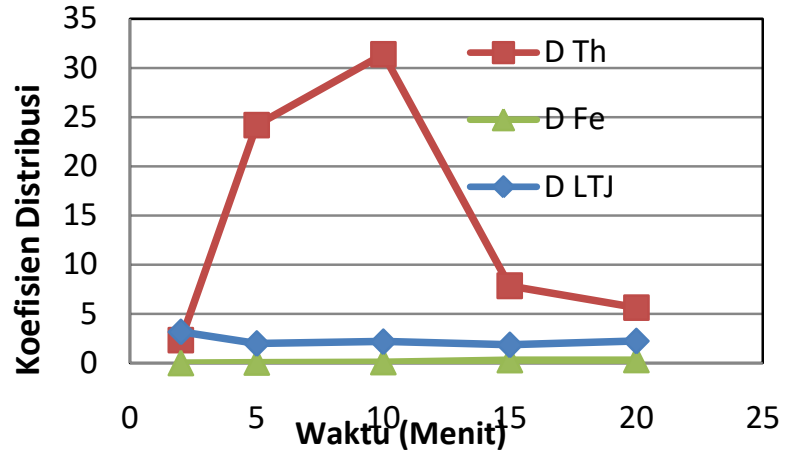

Gambar 10. Profil $\mathrm{D}_{\mathrm{Th}}, \mathrm{D}_{\mathrm{Fe}}$, dan $\mathrm{D}_{\mathrm{LTJ}}$, pada suhu $80^{\circ} \mathrm{C}$, konsentrasi asam 3M, nisbah ekstraktan terhadap diluen 5:100, dan nisbah O/A sebesar 1:1.

\section{Pengaruh Nisbah Ekstraktan terhadap Diluen terhadap Ekstraksi Logam}

Hasil percobaan menunjukkan peningkatan persentase ekstraksi Th seiring dengan peningkatan nisbah ekstraktan terhadap diluen $(\mathrm{g} / \mathrm{mL})$, seperti ditunjukkan pada Gambar 11. Namun, terjadi penurunan ketika nisbah ekstraktan terhadap diluen sebesar 6:100. Hal ini terjadi karena dengan konsentrasi ekstraktan yang tinggi, viskositas larutan organik semakin tinggi sehingga menurunkan laju perpindahan massa ion logam dari fase aqueous ke fase organik. Kecenderungan ini juga ditunjukkan oleh hasil percobaan ekstraksi pelarut thorium dengan menggunakan ekstraktan TOPOkerosin menggunakan bijih awal monasit [11]. Pada percobaan dengan variasi nisbah ekstraktan terhadap diluen ini, hasil yang terbaik diperoleh pada nisbah ekstraktan dengan diluen sebesar 5:100 dengan Th yang terekstraksi sebesar 97,26\%; Fe dan LTJ yang ikut terekstraksi masing masing sebesar $7,97 \%$ dan $62,15 \%$. Profil dengan nilai dari koefisien distribusi Th yang memiliki nilai tertinggi pada persentase ekstraktan sebesar 5:100 ditunjukkan pada gambar 11. Profil $\mathrm{D}_{\mathrm{Th}}, \mathrm{D}_{\mathrm{Fe}}$, dan $\mathrm{D}_{\mathrm{LTJ}}$ sebagai fungsi nisbah ekstraktan terhadap diluen ditunjukkan pada gambar 12 . 


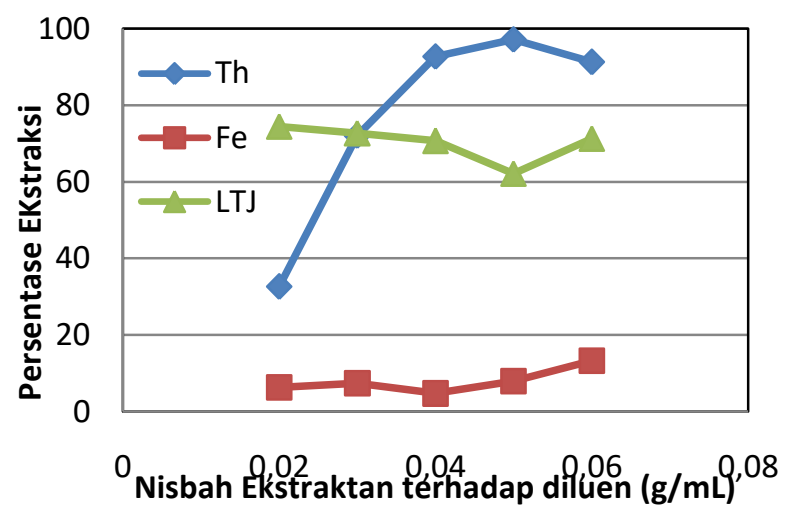

Gambar 11. Persentase ekstraksi Fe, Th, dan LTJ pada suhu $80^{\circ} \mathrm{C}$, konsentrasi asam nitrat $3 \mathrm{M}$, waktu ekstraksi 10 menit, dan nisbah O/A sebesar 1:1.

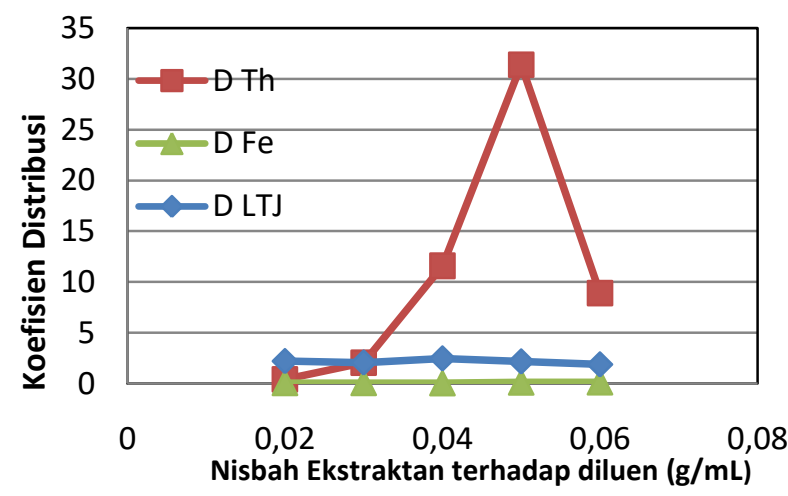

Gambar 12. Profil $\mathrm{D}_{\mathrm{Th}}, \mathrm{D}_{\mathrm{Fe}}$, dan $\mathrm{D}_{\mathrm{LTJ}}$, pada suhu $80^{\circ} \mathrm{C}$, konsentrasi asam 3M, waktu ekstraksi 10 menit, dan nisbah O/A sebesar 1:1.

Dari Persamaan (6), dapat dituliskan koefisien kesetimbangan dari proses ekstraksi thorium dengan TOPO sebagai berikut:

$\mathrm{K}_{\mathrm{Th}}=\frac{\left[\mathrm{Th}\left(\mathrm{NO}_{3}\right) 4 \cdot \mathrm{n} \mathrm{TOPO}\right]}{\left[\mathrm{Th}^{4+}\right]\left[\mathrm{NO}_{3}^{-}\right]^{4}\left[\mathrm{TOPO}^{\mathrm{n}}\right.}$

Apabila harga nisbah konsentrasi Th dalam fase organik terhadap kosentrasi Th dalam fase aqueous dalam Persamaan disubstitusi dengan $\mathrm{D}_{\mathrm{Th}}$ maka akan diperoleh persamaan logaritmik sebagai berikut:

$$
\begin{array}{r}
\log D_{T h}=\log \left(K_{T h}\left[\mathrm{NO}_{3}^{-}\right]^{4}\right)+ \\
n \log [\text { TOPO }]
\end{array}
$$

Dari Persamaan (8) dapat dibuat grafik hubungan antara Log D dengan Log nisbah ekstraktan terhadap diluen seperti yang ditunjukkan pada gambar 13.

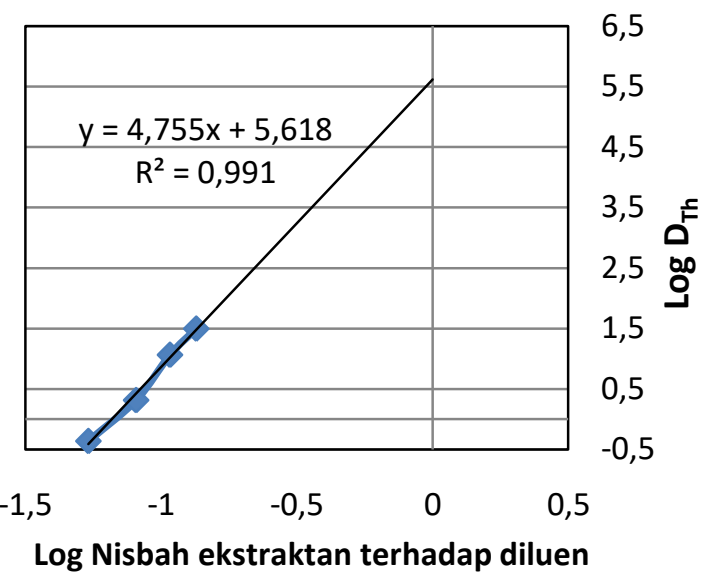

Gambar 13. Grafik antara nilai $\log \mathrm{D}_{\mathrm{Th}}$ terhadap log nisbah ekstraktan terhadap diluen.

Dari grafik diatas didapatkan kemiringan garis yang mendekati 5. Hal ini menunjukkan bahwa 5 mol dari TOPO digunakan untuk mengikat $1 \mathrm{~mol}$ dari Th menjadi kompleks organometallic, atau dapat ditulis persamaan reaksinya sebagai berikut:

$\mathrm{Th}^{4+}+4 \mathrm{NO}_{3}^{-}+5 \mathrm{TOPO}$

$\stackrel{K_{T h}}{\longleftrightarrow} \mathrm{Th}\left(\mathrm{NO}_{3}\right)_{4} .5 \mathrm{TOPO}$

\section{Pengaruh Nisbah O/A terhadap Ekstraksi Logam}

Profil persentase ekstraksi logam pada berbagai nisbah O/A ditunjukkan pada gambar 14. Dari grafik tersebut diperoleh nisbah O/A (v/v) sebesar 1:1 merupakan nisbah O/A (v/v) yang terbaik karena pada nisbah O/A ini nilai persentase ekstraksi Th hampir sama dengan nisbah $\mathrm{O} / \mathrm{A}$, yaitu 2:1 sedangkan volume organik yang digunakan pada nisbah O/A 1:1, lebih sedikit dibandingkan volume organik pada nisbah O/A yang sebesar 2:1. Pada nisbah tersebut, 
diperoleh persentase ekstraksi Th sebesar 97,42 \% dengan persentase ekstraksi Fe dan LTJ masing masing sebesar $7,7 \%$ dan $62,15 \%$.

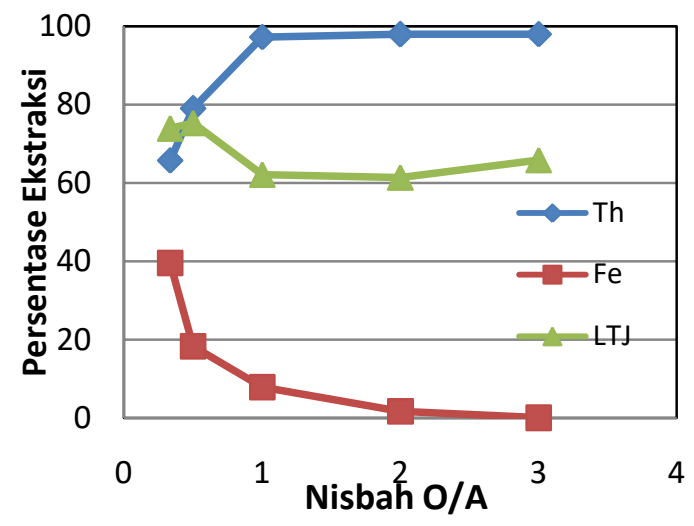

Gambar 14. Persentase ekstraksi Fe, Th, dan LTJ pada suhu $80^{\circ} \mathrm{C}$, kosentrasi asam nitrat $3 \mathrm{M}$, waktu ekstraksi 10 menit, dan nisbah ekstraktan terhadap diluen sebesar 5:100.

Untuk profil nilai $\mathrm{D}_{\mathrm{Th}}, \mathrm{D}_{\mathrm{Fe}}$, dan $\mathrm{D}_{\mathrm{LTJ}}$ sebagai fungsi nisbah O/A ditunjukkan pada gambar 15. Pada nisbah O/A sebesar 1:1 diperoleh nilai $\mathrm{D}_{\mathrm{Th}}$ dan $\mathrm{D}_{\mathrm{Fe}}$, yaitu masing-masing sebesar 31,388 dan 0,115.

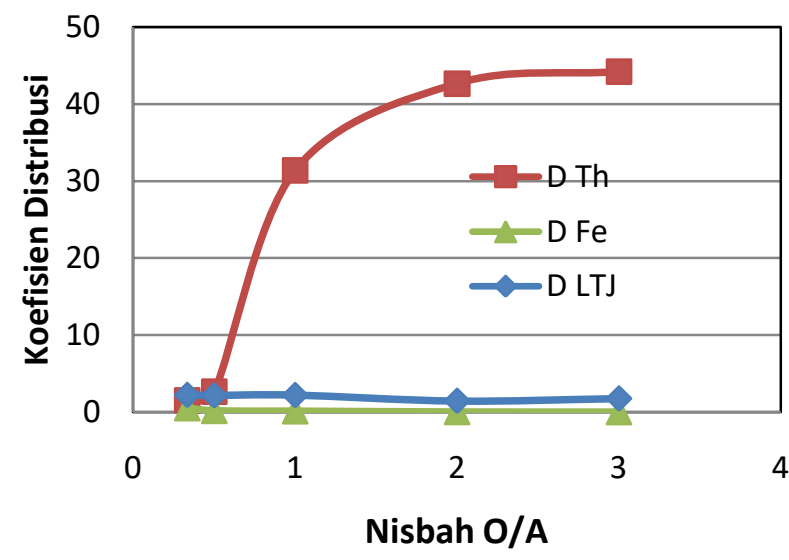

Gambar 15.Profil $\mathrm{D}_{\mathrm{Th}}, \mathrm{D}_{\mathrm{Fe}}$, dan $\mathrm{D}_{\mathrm{LTJ}}$ pada suhu $80^{\circ} \mathrm{C}$, konsentrasi asam 3M, waktu ekstraksi 10 menit, dan nisbah ekstraktan terhadap diluen sebesar 5:100.

\section{Penentuan Jumlah Tahapan Ekstraksi Hipotetik Berdasarkan Konstruksi Diagram McCabe-Thiele}

Diagram McCabe-Thiele dapat dikonstruksi dengan menggunakan kurva isotermal ekstraksi yang diperoleh dari data percobaan variasi nisbah fase yang ditunjukkan pada Tabel 2.

Tabel 2. Kadar Th setelah proses ekstraksi di larutan aqueous dan larutan organik.

\begin{tabular}{ccc}
\hline \multirow{2}{*}{$\begin{array}{c}\text { Nisbah } \\
\text { O/A }\end{array}$} & \multicolumn{2}{c}{ Setelah proses ekstraksi } \\
\cline { 2 - 3 } & $\begin{array}{c}\text { Th yang tersisa } \\
\text { di aqueous }(\mathbf{g} / \mathbf{l})\end{array}$ & $\begin{array}{c}\text { Th di larutan } \\
\text { organik }(\mathbf{g} / \mathbf{l})\end{array}$ \\
\hline $1 / 3$ & 1,4749 & 6,578858 \\
$1 / 2$ & 1,00025 & 5,27165 \\
$1 / 1$ & 0,08055 & 3,229271 \\
$2 / 1$ & 0,0766 & 1,63353 \\
$3 / 1$ & 0,073975 & 1,089808 \\
\hline
\end{tabular}

Diagram isotermal yang terbentuk ditunjukkan pada gambar 16. Dengan kurva tersebut dapat dibuat diagram McCabe-Thiele seperti yang ditunjukkan pada gambar 16. Pertama, garis vertikal ditarik ke atas sejajar dengan sumbu konsentrasi logam pada fase organik dari titik konsentrasi awal umpan $(2,98 \mathrm{~g} / \mathrm{l})$ sejajar dengan sumbu konsentrasi logam pada fase organik ditunjukkan dengan garis berwarna hijau pada Gambar 17. Selanjutnya, dibuat garis operasi dengan gradient $\mathrm{A} / \mathrm{O}$, yaitu sebesar 1:1 yang ditunjukkan dengan garis berwarna hitam. Konsentrasi Th setelah satu tahapan ekstraksi ditunjukkan oleh garis putus-putus berwarna merah. Prosedur yang sama dapat dilakukan untuk menentukan konsentrasi Th setelah tahap kedua dan tahap selanjutnya. 


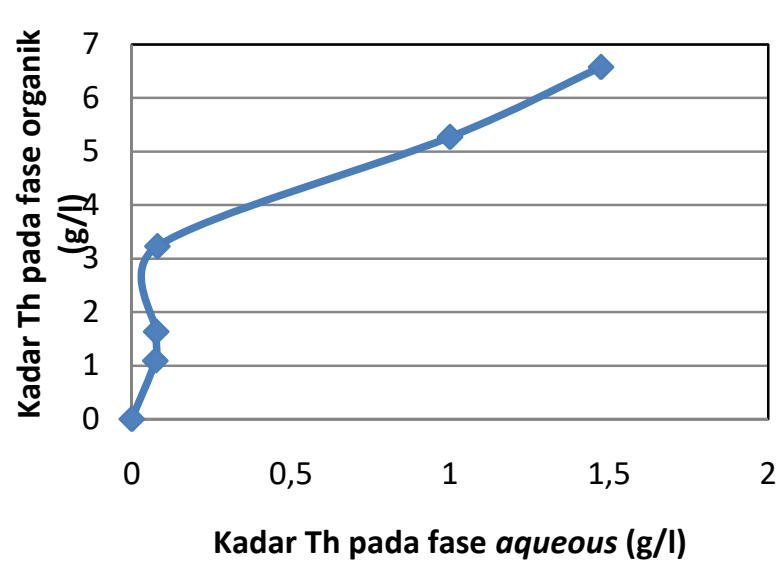

Gambar 16. Diagram isotermal pada konsentrasi asam nitrat 3M, waktu ekstraksi 10 menit, dan nisbah ekstraktan terhadap diluen $(\mathrm{g} / \mathrm{mL})$ 5:100.

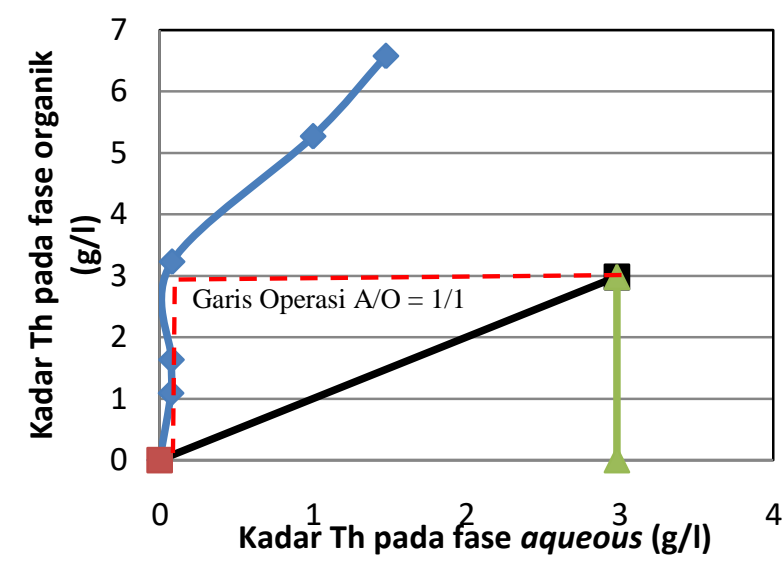

Gambar 17. Diagram McCabe-Thiele untuk ekstraksi Th pada konsentrasi asam nitrat $3 \mathrm{M}$, waktu pelarutan 10 menit, dan nisbah ekstraktan terhadap diluen sebesar 5:100.

Selain dengan menggunakan diagram McCabe-Thiele, tahapan ekstraksi dapat ditentukan juga dengan menurunkan persamaan berikut:

$$
\begin{gathered}
D_{M}=\frac{w_{a}-w_{r} / O}{W_{r} / A} \\
\frac{D W_{r}}{A}=\frac{w_{a}-w_{r}}{O} \\
D w_{r} . O=A \cdot w_{a}-A \cdot w_{r} \\
w_{r}(D O+A)=A w_{a} \\
w_{r}\left(\frac{D O}{A}+1\right)=w_{a}
\end{gathered}
$$

$w_{r}=\frac{w_{a}}{\left(\frac{D O}{A}+1\right)}$

Untuk tahap ekstraksi selanjutnya, $\mathrm{w}_{\mathrm{r}}$ ' didefinisikan sebagai berat logam terlarut yang tersisa dalam larutan aqueous setelah tahap ekstraksi. Maka, konsentrasi dalam larutan aqueous dapat dinyatakan dengan $\mathrm{W}_{\mathrm{r}} / \mathrm{A}$ sedangkan konsentrasi logam dalam fase organik dapat dinyatakan dengan $\mathrm{w}_{\mathrm{r}}-$ $\mathrm{W}_{\mathrm{r}} / \mathrm{O}$. Maka dapat diturunkan lagi persamaan:

$$
\begin{gathered}
D_{M}=\frac{w_{r}-w_{r^{\prime}} / O}{w_{r}{ }^{\prime} / A} \\
\frac{D w_{r^{\prime}}}{A}=\frac{w_{r}-w_{r^{\prime}}}{O} \\
D w_{r^{\prime}} \cdot O=A \cdot w_{r}-A \cdot w_{r^{\prime}} \\
w_{r^{\prime}}(D O+A)=A w_{r} \\
w_{r}{ }^{\prime}\left(\frac{D O}{A}+1\right)=w_{r} \\
w_{r^{\prime}}=\frac{w_{r}}{\left(\frac{D O}{A}+1\right)^{2}}
\end{gathered}
$$

Sehingga untuk ekstraksi sejumlah $\mathrm{n}$ tahap, dapat digunakan persamaan:

$w_{n}=\frac{w_{a}}{\left(\frac{D O}{A}+1\right)^{n}}$

Nilai $\mathrm{w}_{\mathrm{n}}$ adalah berat logam terlarut dalam fase aqueous setelah dilakukan $\mathrm{n}$ tahap ekstraksi, atau dapat diturunkan lagi persamaannya untuk mengetahui konsentrasi logam setelah $\mathrm{n}$ tahap ekstraksi menjadi:

$$
\begin{aligned}
\frac{w_{n}}{A} & =\frac{w_{a} / A}{\left(\frac{D O}{A}+1\right)^{n}} \\
C_{n} & =\frac{C_{a}}{\left(\frac{D O}{A}+1\right)^{n}}
\end{aligned}
$$


Nilai $\mathrm{C}_{\mathrm{n}}$ adalah konsentrasi logam dalam fase aqueous setelah dilakukan $\mathrm{n}$ tahap ekstraksi dan $\mathrm{C}_{\mathrm{a}}$ adalah konsentrasi awal logam pada fase aqueous.

Dari Persamaan (12) dapat dilakukan simulasi perhitungan untuk mendapatkan persentase ekstraksi yang diinginkan dengan nisbah O/A tertentu. Hasil simulasi perhitungan dengan D yang didapat dari hasil percobaan dengan nisbah O/A 1:1 disajikan pada tabel 3 .

Tabel 3.Simulasi perhitungan ekstraksi bertahap untuk nisbah O/A sebesar 1:1.

\begin{tabular}{cccccc}
\hline $\begin{array}{c}\mathbf{C}_{\mathrm{a}} \text { Th } \\
(\mathrm{g} / \mathbf{l})\end{array}$ & $\mathbf{D}$ & O/A & $\mathbf{n}$ & $\begin{array}{c}\mathbf{C}_{\mathrm{a}} \mathbf{T h} \\
(\mathrm{g} / \mathbf{l})\end{array}$ & $\begin{array}{c}\text { \%Ekstraksi } \\
\mathbf{T h}\end{array}$ \\
\hline 2.98 & 1 & 31.39 & 1 & 0.0920 & 96.9 \\
2.98 & 1 & 31.39 & 2 & 0.0028 & 99.9 \\
\hline
\end{tabular}

Berdasarkan hasil perhitungan dengan Persamaan (12) diperoleh bahwa untuk mendapatkan persentase ekstraksi Th lebih dari 99\% dibutuhkan 2 tahap ekstraksi. Hal ini sesuai dengan jumlah tahap ekstraksi untuk mencapai persentase ekstraksi Th lebih dari 99\% yang didekati dengan diagram McCabe-Thiele.

\section{Pengaruh Konsentrasi Asam Nitrat terhadap Stripping Logam}

Proses stripping dilakukan dengan menggunakan asam nitrat yang konsentrasinya lebih rendah dibandingkan dengan konsentrasi asam nitrat yang digunakan untuk melarutkan Th pada presipitat. Dengan demikian diharapkan kesetimbangan dari reaksi yang ditunjukkan pada Persamaan (6) dapat bergeser ke kiri sehingga logam bisa kembali ke larutan aqueous. Hasil percobaan menunjukkan persen stripping Th tertinggi, yaitu sebesar $51,37 \%$ didapatkan pada konsentrasi asam nitrat sebesar 0,3M dengan besi dan LTJ yang ikut ter-stripping masing-masing sebesar $2,72 \%$ dan $2,55 \%$, seperti ditunjukkan pada gambar 18.

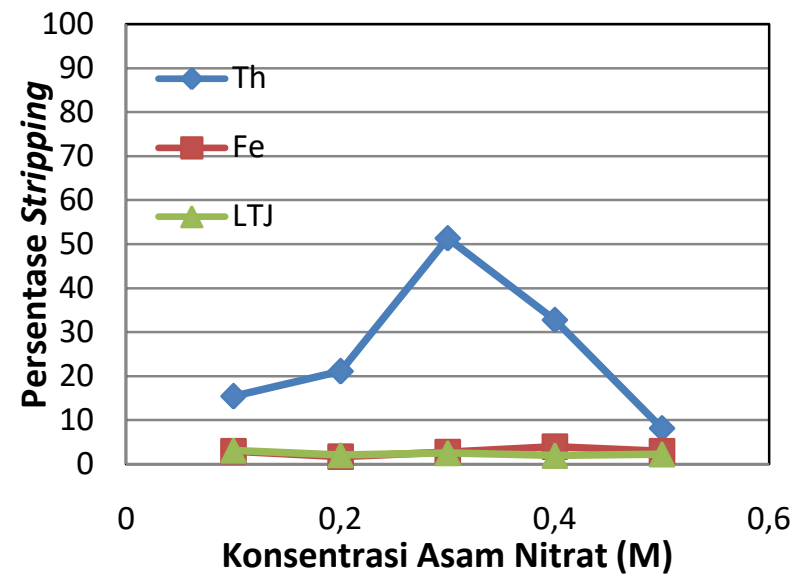

Gambar 18. Persentase stripping Fe, Th, dan LTJ pada temperatur kamar, waktu stripping 10 menit, dan nisbah O/A sebesar 1:4.

Hal ini dapat terjadi kemungkinan karena pada saat stripping, TOPO cenderung mengekstraksi asam nitrat yang digunakan sebagai stripping agent. Meskipun persentase stripping thorium rendah tetapi proses stripping yang dilakukan relatif selektif terhadap besi dan LTJ. Peningkatan persentase stripping Th dapat dilakukan dengan proses stripping bertahap. Waktu stripping perlu dibatasi untuk mencegah terdekomposisi kembalinya kompleks $\mathrm{Th}\left(\mathrm{NO}_{3}\right)_{4} \cdot \mathrm{nTOPO}$ pada konsentrasi asam nitrat dan waktu stripping yang melebihi ambang batas.

\section{KESIMPULAN}

Peningkatan konsentrasi asam nitrat, waktu ekstraksi, nisbah ekstraktan terhadap diluen, dan nisbah O/A cenderung meningkatkan persentase esktraksi thorium oleh TOPO dalam larutan nitrat. Kondisi terbaik yang diperoleh untuk pemisahan thorium dari besi dan LTJ menggunakan ekstraktan TOPO adalah pada konsentrasi 
asam nitrat 3M, waktu ekstraksi 10 menit, nisbah ekstraktan terhadap diluen 5:100 (g/mL), dan nisbah O/A 1:1 dengan ekstraksi thorium dan besi masing-masing sebesar $97,26 \%$ dan $7,97 \%$.

Ekstraksi thorium dengan TOPO dalam media nitrat kurang selektif terhadap LTJ dimana LTJ yang ikut terekstraksi mencapai $62,15 \%$ dengan $\beta_{\text {Th-LTJ }}$ sebesar 14,43. Berdasarkan konstruksi diagram McCabeThiele dan prediksi teoritik berdasarkan data koefisien distribusi Th, pada kondisi konsentrasi asam nitrat $3 \mathrm{M}$, waktu ekstraksi 10 menit, nisbah ekstraktan terhadap diluen sebesar 5:100, dan nisbah O/A sebesar 1:1, persentase ekstraksi thorium dapat mencapai $>99 \%$ dengan dua tahap ekstraksi.

Hasil percobaan stripping thorium satu tahap dengan asam nitrat belum memberikan persentase stripping yang tinggi, dimana pada konsentrasi asam nitrat $0,3 \mathrm{M}$, waktu stripping 10 menit, dan nisbah O/A sebesar 1:4 diperoleh stripped Th sebesar 51,37\% dengan stripped besi dan LTJ masing-masing sebesar $2,72 \%$ dan $2,55 \%$.

\section{UCAPAN TERIMA KASIH}

Penulis mengucapkan terimakasih kepada Pusat Teknologi Bahan Galian Nuklir (PTBGN-BATAN), yang telah menyediakan bahan dan fasilitas yang dibutuhkan untuk melakukan penelitian serta kepada para pegawainya yang telah membantu penulis dalam melakukan penelitian.

\section{DAFTAR PUSTAKA}

[1] “Thorium" [Daring]. Laman: http://www.worldnuclear.org/information-library/current-andfuture-generation/thorium.aspx. [Diakses: 28 April 2017].

[2] Dewan Energi Nasional, Outlook Energi Indonesia 2016, 2016.

[3] H. Tulsidas., Nuclear Fuel Cycle and Materials Section, International Atomic Energy Agency, Thorium reserves in the world.

[4] BATAN, Menguji Kesiapan Thorium sebagai Sumber Energi Alternatif Pembangkit Listrik, 2017.

[5] G. M. Ritcey, Solvent Exctraction Principles and Applications to Process Metallurgy, Vol 1, 2nd Edition, G.M. Ritcey and Associates Incorporated, pp. 1-225, 2006.

[6] M. E. Nasab, Solvent extraction separation of uranium (VI) and thorium (IV) with neutral organophosphorus and amine ligands, In Fuel, Volume 116, 2014, Pages 595-600, ISSN 00162361, https://doi.org/10.1016/j.fuel.2013.08.043.

[7] S. Y. Afifi, E. M. El Sheikh, M. A. S. Elsayed, and M. M. Mustafa, "Extraction and Determination of Thorium and its Application on Geologic Samples using Trioctylphosphine Oxide," Arab Journal of Nuclear Sciences and Application, vol. 45(3), pp. 35-51, 2012.

[8] M. V. Purwani dan Prayitno, "Pemisahan Th dan Ce dari konsentrat serium nitrat hasil olah monasit dengan cara ekstraksi bertingkat", Jurnal Teknologi Bahan Nuklir, Vol. 10, No. 1 (2014): Januari 2014.

[9] A. Alin, M Miloud, A. E. Hossadi, and M Khaliquzzaman, "Solvent Extraction of Thorium from Mixed Organic-Aqueous Nitric Acid Media by Try-N-Octyloxinephosphine Oxide", Journal of Radioanalytical and Nuclear Chemistry, vol. 116 (2), 1987.

[10] F. Xie, T. A. Zhang, D Dreisinger, F Doyle, "A critical review on solvent extraction of rare earths from aqueous solutions", In Minerals Engineering, Volume 56, 2014, Pages 10-28, ISSN 0892-6875, https://doi.org/10.1016/j.mineng.2013.10.021.

[11] M. V. Purwani dan M. Setyadji, "Pengaruh Tri-nOktil Posfin Oksida dan Tingkat Ekstraksi pada Pemurnian Konsentrat Thorium," Eksplorium, vol. 36, no. 2, pp.109-124, 2015. 